\title{
Terapeutelevers svårigheter
}

\author{
Att vara sig själv och att vara avskild
}

\section{GUDRUN OLSSON}

\begin{abstract}
Hur nybörjarterapeuter ser på sina svårigheter under en psykoterapiutbildning undersöks i en kvalitativ studie. Vad är det för typ av svårigheter de möter i patientarbetet? Hur påverkas utvecklingen av en psykoterapeutisk identitet av tidigare utbildning och erfarenhet frän angränsande yrkesområden?
\end{abstract}

Att blivande terapeuter under sin psykoterapiutbildning möter en rad svårigheter är på ett sätt självklart. Att växa in i en ny yrkesidentitet kan omöjligen gå smärtfritt. Att lära sig ett nytt yrke kan jämföras med de utvecklingskriser människan går igenom. Man lär sig stå, man lär sig gå och cykla. Dessa barndomens utvecklingssteg, liksom de stora omprövningstiderna i vuxenlivet, puberteten, småbarnsföräldraperioden, medelåldern och pensionsåldern har ett gemensamt drag. De tidigare erfarenheterna och reaktionssätten är nu inte längre tillräckliga för att bemästra den aktuella situationen. Inför varje sådant språng i utvecklingen ökar ångestbenägenheten. Om den blivande terapeuten genomgår en slags utvecklingskris vari består då denna kris? Hur

Gudrun Olsson är docent, forskare och lektor vid Psykologiska institutionen, Stockholms universitet samt är leg. psykolog och leg. psykoterapeut. Arbetar som privatpraktiserande psykoterapeut, lärare och handledare på psykoterapiutbildningar. tar sig svårigheterna uttryck? Vad betyder det att utbilda sig till psykoterapeut då man har tidigare utbildning och erfarenhet från angränsande områden?

Chessick (1971) ställer frågan vad typ av problem den blivande terapeuten möter. Han urskiljer problem som hänger samman med utvecklingen av en identitet som psykoterapeut, ångest som aktiveras genom utvecklingen av en psykologisk inställning ("psychological-mindedness") och problem som hänger samman med en bristande övertygelse om att lång insiktspsykoterapi är till hjälp.

Enligt Spiegel och Grunebaum (1977) är det stora problemet för nybörjarterapeuten att skilja mellan sitt professionella arbete som terapeut och sin personliga psykologiska stil. De konstaterar det paradoxala att då nybörjareterapeuten börjar kunna särskilja den professionella rollen från den personliga, blir han/hon samtidigt friare att använda sig av hela sin emotionella repertoar. Terapeuten blir helt enkelt mer personlig. 
Om terapeuteleven redan har yrkesutbildning och erfarenhet inom ett speciellt område, exempelvis ett vårdande eller undervisande yrke, vilket har likheter med psykoterapeutyrket, men ändå i avgörande aspekter skiljer sig från detta, torde detta påverka tillägnandet av de psykoterapeutiska färdigheterna. Man kan tänka sig att en rollkonflikt uppstår, då förväntningarna i den tidigare yrkesrollen ej stämmer med de nya förväntningarna. Man skulle också kunna tänka sig att eleven från sitt förflutna tar med sig det som är tillämpbart in i den nya rollen.

Olk och Friedlander (1992) skiljer mellan rollkonflikt och rolltvetydighet (role ambiguity). Rollkonflikt uppträder då en person möter förväntningar i olika roller, som strider mot varandra. Rollerna att vara terapeut, student, patient, handledd och kollega kan kräva beteenden som kommer i konflikt med varandra. I rolltvetydighet vet man ej vad som väntas av en i en speciell roll. Olk och Friedlander (1992) undersökte förekomst av rollkonflikt respektive rolltvetydighet hos handledda terapeuter. Det visade sig att nybörjarterapeuter upplevde betydligt mer av rolltvetydighet än rollkonflikt. De diffusa förväntningarna i den nya professionella rollen gjorde att de ej upplevde någon konflikt mellan olika roller. Nybörjare var upptagna av vad handledarna förväntade sig av dem, hur de skulle bedömas. I nybörjarterapeuters drömmar kunde man se handledaren i skepnad av polis, inspektor, kontrollant eller någon annan typ av auktoritetsfigur med makt att döma, bedöma, bestraffa och även berömma (Olsson, 1991).

Rönnestad och Skovholt (1993) noterade hur det upplevda hotet av handledarens be- dömning får sin näring i den akademiska kulturens prestationsklimat, där det lönar sig att dölja själv-tvivel. Studenter bedöms av lärare. Reflektion kring den egna prestationen uppmuntras ej. Bedömningen kommer utifrån. Detta i sin tur skapar en pseudoutveckling, en utifrånorientering och rigiditet. Komplexitet förnekas. Tekniker och strategier söks. Utforskandet upplevs som alltför tidskrävande.

I Olk och Friedlanders (1992) studie fann man att de mer erfarna terapeutelverna, i jämförelse med nybörjarna, upplevde betydligt mer rollkonflikt än rolltvetydighet. För dem framstod bedömningskriterier och förväntningar som relativt klara. En rollkonflikt kunde exempelvis ta sig följande uttryck. Samtidigt som terapeuten i rollen som handledd elev förväntades följa handledarens rekommendationer, förväntades det att han/hon i rollen som terapeut till patienten skulle vara självständig.

Den blivande terapeutens utveckling beskrivs vanligtvis utifrån olika stadier, som han/hon kan tänkas genomgå (Olsson, 1993; Rönnestad \& Skovholt, 1993). Terapeuten brottas således med olika problem beroende på utvecklingsnivå. Handledningen blir effektiv endast då den fångar upp terapeuten där han/hon befinner sig. Exempelvis upplever nybörjarterapeuter en mycket stor klyfta mellan teori och praktik. De vill så snabbt som möjligt komma över det lidande som är förenat med denna diskrepans, vilket ofta tar sig uttryck i snabba åtgärder utan reflektion. Om inte den professionella reflektionen får utrymme i handledningen löper terapeuteleven - på detta inlärningsstadium liksom på alla andra nivåer- risken att snabbt stagnera. 
En iakttagelse som många gjort är att ångestnivån är hög hos nybörjare. Emellertid visade det sig i en studie (Skovholt \& Rönnestad, 1992) att nybörjare ej avslöjar denna ångest då de intervjuas. De förnekar sin ångest och sin inkompetens. Först då deras erfarenhet vuxit och ångesten avtagit kan de retrospektivt berätta om den. Liknande resultat erhölls i en studie (Olsson, 1996a) där terapeutelever skattade sina terapeutiska färdigheter i början och i slutet av en psykoterapiutbildning. Det visade sig att de redan i början ansåg sig besitta en hel del färdigheter. Denna bild kom emellertid att avsevärt förändras. När de blickade tillbaka mindes de sig själva som mycket osäkra och inkompetenta. Detta kan ses som ett uttryck för en obalans i självkänslan, en obalans som är nödvändig för att inlärning skall kunna äga rum. Nybörjare försöker på olika sätt att öka sin självkänsla och engagèrar sig därför i manövrer i syfte att få patientens gillande och i syfte att undvika negativ överföring (Buckley, Karasu \& Charles, 1979).

Ralph (1980) gjorde i en kvalitativ studie intervjuer med terapeutelever och handledare och tillfrågade dessa om hur inlärning av psykoterapi kunde tänkas gå till. Intervjuerna gjordes retrospektivt. Fyra steg $i$ inlärningsprocssen identifierades. Problem kan uppstå på varje steg.

(1) Det första steget handlar om att lära sig att vara icke-styrande. Bilden av en expert är en person som auktoritativt erbjuder lösningar på problem, ger råd. Denna common sense betydelse av expertrollen tillämpas då terapeuteleven börjar sin utbildning. Han/hon vill ge patienten något konkret och påtagligt. Annars framstår sessionen som ett misslyckande. Inte minst under intervjun med patienten märks hur terapeutens föreställning om en expert fungerar: Terapeuten strukturerar upp interaktionen, ställer en mängd frågor, varvid patienten oftast blir mer och mer passiv.

(2) Nästa steg handlar om att anamma en patient-centrerad approach, som är konkret och innehållscentrerad. Det är patienten som tilldrar sig elevens intresse, vad patienten känner och tänker. Terapeuteleven tror att han/hon skall ge insikt på ett ganska direkt sätt, liksom lösa patientens livsgåta.

(3) På det tredje inlärningssteget upptäcker eleven att psykoterapi är en interpersonell process, som involverar både patientens och terapeutens reaktioner. Detta är ett relationscentrerat sätt att arbeta på. Eleven befinner sig inte längre bara på en konkret nivå med fokus på sessionens innehåll och vad patienten berättade. Eleven är beredd att betrakta kommunikationen på en meta-nivå, där han/hon ser att känslor som utvecklas i relationen mellan patient och terapeut genererar sessionens innehåll. Detta är en kraftfull upptäckt.

(4) Det fjärde inlärningssteget utmärkes av ett terapeutcentrerat närmande, där terapeuteleven inser användbarheten av egna känslor för förståelse av patienten. Han/hon litar på egna reaktioner, litar på sin intution och blir mer spontan.

Sammanfattningsvis är terapeuteleven i början av sin utveckling konkret, odifferentierad, har fokus på patienten och fokus på det yttre med en common senseuppfattning om psykoterapi. Senare i utvecklingen är han/hon självmedveten, gör en introspektiv analys av relationer och blir mer abstrakt med fokus på det inre och det komplexa.

Många ansatser har gjorts för att identi- 
fiera tänkbara stadier som terapeutelever genomgår. Emellertid saknas systematiska studier över vad blivande terapeuter själva upplever som svårt och problematiskt i terapiarbetet under den tid de går en psykoterapiutbildning.

Denna studie syftar till att kartlägga hur blivande psykoterapeuter upplever sina svårigheter $\mathrm{i}$ arbetet med patienter under loppet av en psykonalytiskt inriktad psykoterapiutbildning. Vad är det för sorts svårigheter de möter? Vad lägger de för innebörd i svårigheterna? Upplevs svårigheterna på ett kvalitativt annorlunda sätt i början respektive i slutet av utbildningen? Hur kan tidigare utbildning och erfarenhet av angränsande områden i hjälpande eller pedagogiska professioner tänkas påverka utvecklandet av en psykoterapeutisk identitet? Att samtidigt vara väl förankrad i den hjälpande kuratorsrollen och att vara nybörjare i den hjälpande psykoterapeutrollen torde aktualisera frågan vad hjälp till en annan människa egentligen kan bestå av.

\section{Metod}

\section{Undersökningsgrupp}

En grupp på 35 nybörjarterapeuter, 29 kvinnor och 6 män, som gick en grundläggande utbildning i psykoterapi, deltog i studien. Fem personer var läkare, 19 kuratorer, 3 sjuksköterskor, 2 förste skötare, 4 filosofie kandidater i beteendevetenskapliga ämnen, 1 speciallärare och 1 fritidspedagog. Personerna ombads reflektera över vilka svårigheter de tyckte sig möta i arbetet med patienter och vilken innebörd de lade i dessa svårigheter. I början och i slutet av utbildningen gjordes intervjuer eller terapeuterna skrev ned sina reflektioner så utförligt som möjligt. Då intervjuer gjordes, skrevs intervjusvaren ned under själva intervjun och kompletterades efter denna. Intervjun avslutades då ämnet framstod som uttömt.

\section{Psykoterapiutbildningen}

Den psykoterapiutbildning som terapeuterna genomgick löpte över 1 l/2 år. Den omfattade 240 timmar undervisning i psykoanalytisk teori, 120 timmar psykoterapihandledning på eget patientarbete (en eller två patienter) samt minst 50 timmar egen individualterapi eller minst 120 timmar gruppterapi.

Följande delkurser ingick i den teoretiska delen av utbildningen: Personlighetsutveckling och psykopatologi (82 timmar), Intervjuteknik och samtalsmetodik (24 timmar), Psykoterapeutiska metoder (110 timmar), Vetenskapsteori och utvärderingsmetoder (12 timmar) samt Orienterande information om olika terapiformer (12 timmar).

\section{Kvalitativ analys}

En kvalitativ analys av terapeutelevernas intervjusvar och reflektioner gjordes. Denna typ av analys är speciellt lämplig med tanke på frågeställningens öppna, explorerande karaktär. Analysen har gått till så att jag läst varje uttalande om svårigheter. Jag har kategoriserat dem utifrån tematisk likhet. Jag har inte bara gjort en analys av innehållet $\mathrm{i}$ svårigheterna utan har också tagit hänsyn till hur något uttrycks. Är terapeutens beskrivning oartikulerad, oprecis, stum? Försöker han/hon fånga komplexiteten? Finns en tolerans för motstridighet?

Analysen har både en deskriptiv och tolkande ansats. Det deskriptiva inslaget 
består i att jag så noggrant som möjligt återger terapeutens egen beskrivning. Tolkningen innebär att jag söker en förståelse av vad som sägs bakom de manifesta uttrycken. Jag söker innebörder och mening. Jag har empatiskt försökt lyssna till terapeutens upplevelse. Hur ter sig svårigheterna utifrån terapeutens perspektiv och utifrån den position han/hon befinner sig i? Vad väcker terapeutens reflektion för reflektion hos mig? Om terapeuten använder metaforer som att gå runt i ett träsk, att åka-berg-och dalbana, att kunna hảlla alla bollar i luften samtidigt, vad vill terapeuten förmedla med dessa förtätade bilder?

Hur man kan förhålla sig till validiteten $i$ kvalitativa studier har diskuterats (Olsson, 1996b). Man brukar tala om deskriptiv, tolkande och teoretisk validitet. Hur valida är då de tolkningar jag gjort? Hur väl sammanhängande är de? Hur meningsfulla för läsaren är de? De tolkningar jag givit är inte de enda möjliga. Däremot vill jag hävda att de utgör ett möjligt perspektiv, en förståelsehorisont.

\section{Resultat}

\section{Början av utbildningen \\ Den osynliga patienten}

Terapeuten kan uppleva patienten som sitt största problem. Som kommer att framgå av exemplen nedan, beskrivs emellertid patienten på ett knapphändigt och oartikulerat sätt. Man får ett intryck av att terapeuten ej mött en separat person i sin patient. Det är som patienten är osynlig för terapeuten. De känslor och reaktioner som patienten väcker hos terapeuten har även en ospecifik karaktär, mest präglade av olust. Påfal- lande är hur lätt terapeuten låter sig dras med i patientens känslor. Terapeuten förlorar sin separathet.

EX. »Problemet är att jag har en patient som det är som att gå runt i ett träsk tillsammans med, alla dörrar är stängdau. Metaforen att vara oupplösligt förenad med patienten i ett träsk, att inte komma upp och ut, är en stark bild och innehåller förmodligen mycken ångest.

Ex. »Min patient är så rädd för de känslor som kan komma fram och därför har jag svårt att arbeta med hennes motståndu. Patientens rädsla, oartikulerad och oförstådd som den framstår, påverkar alltså terapeuten så att hon avstår från att göra något hon tror att hon borde. Terapeuten tycks använda patientens rädsla som en ursäkt för eget beteende.

EX. »Patienten började prata så mycket om sex, det blev så intimt. Jag borde ha frågat vidare, men jag kände mig som voyeur. På sätt och vis är vi ju alla voyeurer $i$ vårt job« Känslan av att se något förbjudet får alltså terapeuten att dra sig tillbaka, något han betraktar som ett misstag. Hur patienten talar om sin sexualitet avslöjar ej terapeuten. I en lite överslätande ton, svi är alla voyeurer ger terapeuten sig själv tröst.

EX. "Jag har svårt att hålla distans och inte bli för social inför patientens kast, hennes berg-och-dalbanau. Här kan vi anta att terapeuten tenderar att säga för mycket och att göra för mycket, då hon låter sig dras med av patientens emotioner. Patientens inre tumult har en oprecis karaktär.

Exemplen illustrerar också två typer av misstag som terapeuter ofta upplever sig göra. Man gör för lite ("errors of ommision") då något borde ha gjorts, sagts eller ut- 
tryckts. Man gör för mycket (uerrors of commission") då man borde ha avvaktat och hållit sig tillbaka. Dessa misstag löper -som vi kommer att se- som en röd tråd genom hela materialet.

En speciell typ av problem är de som är generaliserade till en speciell patientkategori eller en speciell problematik hos patienten. Exempelvis beskriver en terapeut hur hon känner sig osäker och generad inför yngre mäns homosexuella problematik. En annan terapeut finner att tvångsmässiga patienter får honom att uppleva terapin som trög och stillastående, medan ytterligare en annan terapeut beskriver hur hon retar sig på missbrukare och anstränger sig att inte visa det. Vi ser återigen hur terapeuterna på nybörjarnivå förmår att fånga endast det generella och hur trevande och vagt de uttrycker sig.

När man börjar en psykoterapiutbildning kan den mest påtagliga svårigheten bestå av att finna en lämplig, neurotisk patient. När man så lyckats, inställer sig nästa svårighet, att behålla patienten! EX. "Jag var mycket orolig att patienten skulle sluta. Hon hotade med det«. Om terapeutens inställning är att till varje pris behålla patienten, skapas en utbildnings-inducerad motöverföring, där patienten går i terapi mer för terapeutens skull än för sin egen. Detta är ytterligare ett sätt att osynliggöra patienten och dennes behov. Terapeuten exploaterar patienten för egna syften.

\section{Rollkonflikt:}

\section{Förr var allt mänskligt tillåtet}

Den tidigare yrkesrollen, exempelvis yrkesidentiteten som kurator, familjerådgivare, socialsektreterare, läkare, står i konflikt med den roll som nu skall läras in. Det kan röra sig om ett annorlunda förhållningssätt mot patienter, en annan metod, en annan teori, en annan syn på vad som är till hjälp för andra, möte med en annan typ av patienter. Sökandet efter en optimal balans mellan gratifikation och frustration blir märkbart då det gäller svårigheter upplevda i samband med rollkonflikter. Inte sällan framstår den tidigare yrkesrollen som fylld med gratifikation till patienter, medan den nya rollen tycks fylld bara av frustratration.

EX. "Svårt att undvika att bli stödjande och förklarande. Jag vill gärna ge patienten tröst när hon har det svårt. Ett problem är också att vara tyst, när patienten tvekar. Jag är dock medveten om detta hos mig själv och lyckas för det mesta vara tyst. Svårigheten beror nog på att jag, som kurator, träffar många människor i mitt dagliga arbete, som behöver stöd, kanske praktisk, konkret vägledning, t.ex. i rehabiliteringw. Av exemplet framgår att terapeuten förknippar givande av stöd och tröst med sin vardagliga yrkesroll, medan kraven under utbildningen förstås som mycket annorlunda. Terapeuten förstår det som att ett stödjande förhållingssätt är anti-terapeutiskt.

EX. »Som kurator arbetar jag mer aktivt och styrande i mitt arbete med par och med korttidsterapi på familjerådgivningen. Detta gör att jag nu tycker det är svårt att inte gripa in och därmed störa den process som pågår, att stoppa upp. Det är svårt att också kunna vara aktiv och föra processen vidare." Terapeuten söker efter en balans i sitt förhållningssätt.

EX. "Jag har vårdat tungt psykotiska patienter; det är svårt att nu inte få ge råd och stöd. Jag är van vid stödterapi. Patienten 
frågar om mig som person, och jag får absolut inte säga något«. Terapeuten upplever det som att hennes erfarenheter av en annan typ av patienter ej är applicerbara i det nya sammanhanget. En stödjande hållning ser hon som omöjlig att inta i den nya rollen. Av speciellt intresse i detta exempel är det överjagsbetonade påbudet att inte få lov att säga något om sig själv. Förståelse för denna regel saknas, och regeln blir bara ett förbud utan riktig mening.

EX. »Jag har varit distriktsläkare ett antal år och bedrivit terapi, men jag kallar det inte terapi. Jag är inställd på att gå patienter till mötes. Detta är en nackdel. Då patienten lämnar återbud, godtar jag skälen för snabbt«. Vad denna terapeut brottas med är hur han skall förstå innebörden av patientens återbud. I sin tidigare yrkesroll har han bara lyssnat till manifesta budskap. Han har inte utforskat motiven bakom handlingar. Dessutom tycks han tro att det nya förhållningssättet innebär ett förbud om att gå patienter till mötes.

EX. "Det svåra är att gå ifrån sin vanliga roll som kurator. Jag jobbar annars mer stödjande. Jag måste nu koppla av kontakten med myndigheter. Jag vill det ska hända saker. Det är svårt att vara på patientens nivåu. Att inte ta över ansvaret för patienten är utmaningen i den nya rollen.

\section{Att inte tala om den relation som pågår}

Att använda den terapeutiska relationen som en möjlighet till att förstå patienten är terapeuterna inte särskilt upptagna av i början av utbildningen. Av de få exempel som finns, kan man ändå ana att denna typ av metakommunikation innebär specifika svårigheter för nybörjarterapeuten.
EX. "Svårigheten att få till stånd en process mellan mig och patienten i rummet, ta in mig själv i terapin med patienten. Jag kanske inte har kommit så långt med patienten ännu i terapin; jag kanske är tidigt ute». Det låter som att terapeuten anar att metakommunikation är ett viktigt terapeutiskt instrument men är fortfarande mycket frågande inför hur sådan kommunikation kan gå till.

EX. "Tidigare har jag varit ovan att prata om relationen mellan mig och patienten. Det har varit jättenyttigt att lära sig det, att använda sig själv, rakt i rummet; det blir nära en själv." Denna terapeut har förstått att intensiteten och den emotionella närheten mellan patient och terapeut ökar, då terapeuten tar initiativ att tala om relationen.

EX. "När hon (patienten) kommer in på mina personliga saker, då hon säger något om mina nya glasögon, mina nya kläder, det är svårt. Hon sa: så mörkt här är. Hur vågar du sitta här?. Hon tycker synd om mig och tar hand om mig. Jag ger akt på det. Patienten sa en gång att jag såg väldigt trött ut, och det var jag. Det var svårtı. Terapeuten förmedlar en känsla av genans inför patientens personliga kommentarer. Terapeuten känner sig avslöjad då patienten gjort en riktig iakttagelse av terapeuten. Det är inte särskilt sannolikt att terapeuten förstått vad patienten omedvetet velat kommunicera till terapeuten. Om dock en rudimentär förståelse funnits, har denna säkerligen ej formulerats till patienten.

\section{Den goda givande modern}

Ofta förmedlar terapeuteleven en föreställningen om sig själv som god, oändligt givande, generös, alltid till hands, alltid tillmötes- 
gående. I synnerhet önskar man att det förhöll sig på det sättet. Myten om den goda modern blir till ett ideal.

Då önskningarna möter verkligheten den goda modern kan omöjligen vara så goduppstår en inre konflikt.

EX. »Det är svårt att nollställa sig själv, att lyssna, slappna av, svårt att inte hinna reflektera över det patienten säger, att se vad som händer. Detta beror på att jag vill vara snäll, artig och tillmötesgåender. Det tycks som om terapeuten är så upptagen av sin önskan om att vara god och tillmötesgående att hon faktiskt glömmer bort sin patient och därmed blir allt annat än god.

EX. "Svårigheterna för mig är nog att kunna hålla tiderna, dvs ramarna. Vi drar ofta över på tiden, och jag har svårt att avsluta. Detta förekom framförallt i början av terapin; det är lättare nu. Att vi dragit över på tiden handlar för min del om en slags generositet, tror jag. Jag känner en ovilja att avvisa om något kommer upp mot slutet av timmen«. Om terapeuten skulle avsluta sessionen $i$ tid, skulle föreställning om sig själv som generös rubbas.

EX. "Jag har svårt att undvika att bli stödjande och förklarande. Jag vill gärna ge patienten tröst när hon har det svårt och när hon gråter" . Terapeutens omhändertagande aktiveras inför det lilla barn som hon möter $i$ patienten. Dessutom tycks terapeuten tro att en stödjande hållning är förbjuden.

Önskan att vara god och generös möter på ett alldeles speciellt hinder. På utbildningen hör man nämligen ett påbud om frustration, avhållsamhet, neutralitet. Man får inte ge det goda längre, det som alltid fungerat så bra! EX. "Svårt är att alltid ha en neutral grundinställning, att förhålla sig mycket lite personlig, att inte få lov att delge andra sina erfarenheter. Dessa svårigheter beror på att jag gärna vill dela med mig av mig själv - på gott och ont - vill skämta ibland, jag vill vara skapande, aktiv; jag vill att saker ska hända.» Exemplet illustrerar hur trist det nya förhållningssättet kan te sig, förbuden hopar sig. Det är som att man inte längre kan använda sig av sin erfarenhet och kreativitet. Humor tycks förbjuden. Man blir sträng mot sina patienter och sträng mot sig själv. Hela utbildningssituationen får en prägel av överjag.

Ytterligare ett exempel visar hur gärna man vill ge patienten något gott men tror att det är förbjudet. EX. "Jag har svårt att avhålla mig från att säga eller visa vad jag tycker patienten gör brau. Terapeuten uppfattar således att det skulle vara anti-terapeutiskt att ge uppmuntran och positiv feedback till patienten. Istället för att söka en optimal balans mellan frustration och gratifikation, arbetar terapeuten på linjen att bli maximalt frustrerande.

\section{Den perfekta eleven}

En ofta förekommande föreställning om sig själv är att vara duktig, felfri, perfekt, utomordentligt skicklig. Än oftare tar sig föreställningen uttryck i en önskan om att vara perfekt och förstå allt utan ansträngning. Det är inte speciellt långsökt att tänka sig att då man befinner sig på en utbildning/i en handledning, aktiveras åter tidigare erfarenheter av att vara elev. Skolan har onekligen satt sin prägel på oss. Kraven från de första skolåren på att kunna läxan, rabbla floder, psalmverser och fältslag och den därpå följande blockeringen inför lärarens uppfordrande blickar utgör för många prototy- 
pen för inlärningen i nuet. De akademiska studiernas tentamenshets, poängsättningen och kvantifieringen av kunskap, har ytterligare ökat prestationskraven. Det är dessa krav som den blivande terapeuten bär i sitt bagage då han/hon kommer till psykoterapiutbildningen. Förståelse, eftertanke, introspektion och reflektion är förmågor som nästan tynat bort.

Följande exempel får illustrera svårigheter, bakom vilka man kan ana föreställningen om den perfekta eleven.

EX. "Jag har svårigheter med att hantera tystnad, upplever att jag måste göra något för att bryta tystnaden. Vid tystnad kryper det i kroppen på mig. Jag har förmodligen för stora krav på migu. Terapeuten upplever här alltså ett slags inre tvång att göra något vid uppkommen tystnad, då han tror att han egentligen borde låta bli. Tystnaden, som skulle kunna utgöra ett rum för reflektion, förvandlas till krav. Dessutom visar exemplet den svåra balansen mellan gratifikation och frustration. Varför skulle terapeuten inte kunna bryta tystnaden för att underlätta dialogen!

EX. "När patienten har motstånd mot terapin och inte vill komma eller inte vill säga något är det svårt. Det är svårt med tystnad och med kallprat. Patienten har motstånd, och jag är rädd att hon ska sluta. Man har för bråttom och vill att något ska hända. Man har fokus på sig själv för mycket«. Det tycks som om terapeuten här tenderar att vara för aktiv som ett sätt att motverka patientens för tidiga avslutning av terapin. Patientens skallpratı väcker terapeutens prestationsångest. Terapin har kommit att förlora sin prägel av frivillighet, troligen ett uttryck för utbildnings-inducerad motöverföring.
EX. »Handledaren lägger en press på mig att jag måste få patienten att kommaı. Terapin är inte längre patientens projekt, inte heller terapeutens. Det är handledaren som upplevs vara den terapiangelägna personen. Det blir således inför handledaren som den duktiga terapeuteleven skall visa upp sin duktiga patient.

EX. "Jag tycker att det är svårt att stå ut med tanken att jag kanske inte är tillräckligt duktig som terapeut. Jag har kanske för stora krav på mig själv, krav att prestera». Ordvalet sduktig, får osökt tankarna att gå till den duktiga eleven.

EX. „Den ena av mina patienter reflekterar mycket litet över sig själv, vilket gör det svårt att få en klar bild av honom. Jag känner en inre stress, krav på mig att förstå och veta vad som är problemet. Jag har höga krav på mig självu. Man kan nog höra terapeutens djupa önskan om lindring av prestationskraven och en önskan om att patienten kunde göra det förståelsearbete som terapeuten tycker sig gå bet på. Hon tycks förvänta sig av patienten att hans förmåga att reflektera skall vara väl utvecklad redan från början av terapin. Hur terapeuten ser på sin egen förmåga till reflektion avslöjar hon ej.

EX. »Det är svårt att ställa tillräckligt bra frågor, som leder terapin framåt, att komma på dem just i terapisituationen. Denna svårighet beror på att jag är upptagen av att tänka satt det ska bli brar. Jag vet att jag ska redovisa, har kanske för mycket prestationsångest». Denna terapeut tycker alltså att prestationskraven stör den naturliga nyfikenheten. Hon tycks tro att psykoterapi handlar om någon slags frågesport. Kravet på redovisning inför handledaren blir till en utbildnings-inducerad motöverföring. 
Exemplen illustrerar hur prestationskraven hindrar en naturlig kontakt med patienten. Terapeutens fritt flytande uppmärksamhet, flyter i en och samma riktning -och är alltså allt annat än fri- och utmynnar i frågan "Duger jag»? De krav som man så starkt upplever har förstås ett ännu tidigare ursprung än själva skolåren. Kraven kommer från uppfostran i de tidiga barndomsåren. Freud (1920) skriver: "...de stegrade krav som uppfostran ställde, stränga tillsägelser och ibland bestraffningar hade till sist avslöjat i hela dess vidd hur försmått och förkastat det/barnet/varı.

\section{Slutet av utbildningen}

\section{En patient blir synlig}

Även mot slutet av utbildningen/handledningen upplevs patienters problem som svårigheter för terapeuten. De känslor och reaktioner som väcks hos terapeuten genom mötet med patienten beskrivs. I jämförelse med början av utbildningen får man dock här ett intryck av att patienten börjar ta mer plats i terapeutens värld. Terapeuten ser sin patient. Beskrivningarna blir betydligt mer nyanserade. Komplexiteten blir möjlig att hantera och att uttrycka.

EX. "Den andra patienten jag har, en kvinna, har varit mycket reflekterande och har stor kapacitet. Problemet har mer gällt hennes något avvaktande hållning. Det har inte varit någon direkt varm atmosfär, men inte kylig heller. Jag har inom mig känt en viss stress i mötet med henne. Hon är mycket intellektualiserande och möter människor på den nivån -också mig. Hon har lätt till konkurrens och särskilt till jämnåriga, enligt henne själv. Vi är ungefär lika gamla.» Terapeuten letar efter orden som skall fånga en atmosfär och ett skeende, där både terapeuten själv och patienten får utrymme.

EX. "Med en patient kan jag känna svårigheter med att stå ut med längre depressivitet i den meningen att jag försöker bekräfta patienten för att hon skall se lite ljusare på tillvaron. Detta beror på att jag har svårt med denna patients dolda aggressivitet bakom det depressivar. Patienten beskrivs nyanserat i den meningen att dold aggressivitet fångas upp. Det är troligt att terapeuten -medvetet eller omedvetet- tolkar patientens dolda aggressivitet som riktad mot sig själv. Att ıbekräftar patienten kan då vara ett sätt att avvärja agressionerna.

EX. "Jag kände mig ofta hotad när patienten sa att hon ville sluta, vilket hon sa flera gånger mitt $i$ terapin. När hon sa att andra terapier var bättre för henne, indirekt kritik, var också jobbigt. Svårigheten berodde på att jag inte kände mig helt säker på att det var bra för henne med den iterapeutiska distansen. Hon kanske behövde mer beröm och närhet och trygghet som hon inte fătt av sin mamma». Beskrivningen av patienten är konkret och nyanserad. När patienten riktar kritik mot terapeuten och mot terapiformen, introjicerar terapeuten snabbt denna kritik. Någon övertygelse hos terapeuten om att det är något värdefullt som hon ger, finns ännu inte.

EX. »Det är känsligt när min patient blir alltför kritisk och vill att jag ska svara på frågor. Hon har väldiga prestationskrav, vilka jag tror mig omedvetet vilja svara upp mot, och därför har jag svårt att ta att hon kritiserar. Jag har också egna prestationskrav«. Kritiken från patienten känns svår, i synnerhet därför att terapeuten troligen misstänker att hon själv genom att vägra gå patienten 
till mötes och svara på frågor har framkallat ilska hos patienten. I beskrivningen finns ett särskiljande mellan patientens prestationskrav och terapeutens egna.

Det framgår av många exempel att terapeuter tycker det är speciellt svårt då patienter direkt eller indirekt kritiserar dem eller kritiserar terapin. De omvandlar ofta denna kritik till självkritik. Erfarenheten av att det nya förhållningssättet skulle kunna vara av terapeutiskt värde saknas.

\section{Rollkonflikt:}

\section{$\mathrm{Nu}$ är allt mänskligt förbjudet}

Svårigheter i samband med rollkonflikter förekommer fortfarande vid slutet av utbildningen. Exempelvis vänder man blicken framåt mot den verklighet som väntar då utbildningen och handledningen avslutas: "Handledningspatienterna har ju trots allt varit förhållandevis okomplicerade (även om deras problematik i och för sig varit djupgående) eftersom de ändå valts ut efter viss begrundan -de skulle ju inte vara alltför svårar. Problemet är istället alla svanligar patienter med djupa störningar där jag utan handledning skall balansera en terapeutisk hållning mot krav på sjukskrivning etcu.

Man ser också tillbaka och minns hur frestande det varit att utifrån en tidigare yrkesroll agera och ta över ansvar från patienten: „Kanske inte direkt svårt, men vad jag fått vara vaken på någon gång är att inte glida in i att vara mer stöd, att vara den som t.ex. följde med till en abort utan styra dithän att det fanns någon annan som gjorde detta, att jag förblev terapeuten och att jag och patienten hade vårt rum."

Det är inte bara tankar på framtiden och det förflutna som aktualiserar rollkonflik- ten utan också den nuvarande arbetssituationen som terapeuten befinner sig i. Fortfarande är man upptagen av problemen med en stödjande, gratifierande hållning, som ter sig så svår att integrerar i ett terapeutiskt förhållningssätt: "Svårt har varit att frigöra mig från det sätt som jag arbetar på med patienter i mitt ordinarie arbete, svårt att undvika vara stödjande, tröstande. Det beror också på min personlighet att jag vill vara ssnäll, lindra lidande».

Ytterligare ett exempel visar den smärta det innebär att lämna det man tidigare har trott på: "Jag är ovan vid den terapeutiska rollen. Jag har tidigare under min arbetstid arbetat stödjande. Svårigheten består i att lämna det som är gammalt och invant hos mig, vilket aktualiserar egen övergivenhetsproblematik som jag genom egenterapin arbetat med. Svårigheten tar sig uttryck i att jag lätt blir för aktiv och stödjande när ångesten är hög hos patienten".

\section{Att tala om den relation som pågår}

I början av utbildningen fästes ingen nämnvärd uppmärksamhet vid terapirelationen. Detta har radikalt förändrats i slutet. Majoriteten av terapeuterna ser nu arbetet med den terapeutiska relationen som en verklig upptäckt, en stor utmaning och en svårighet. Vi kan dra slutsatsen att man i början var så främmande inför tanken att använda sig av den terapeutiska relationen, att man inte ens låtit denna möjlighet sjunka in $\mathrm{i}$ medvetandet.

Följande exempel visar hur känsligt och besvärande det kan upplevas att tala om relationen mellan patient och terapeut. En djupare förståelse för innebörden av terapirelationen är ännu ej möjlig. Beskrivningar- 
na är relativt onyanserade. Man befinner sig mer $i$ ett läge av förvåning inför den nya upptäckten.

EX. »Det har varit ovant men mycket lärorikt att föra in relationen terapeut - patient som en stor del $i$ arbetet. P.g.a. ovanan kändes detta som en känslig och svår del att ta upp med patienten till en början".

EX. »Att föra in mig som terapeut i relationen med patienten här- och- nu. Det känns ibland fånigt att föra in mig $i$ relation till patienten, men det går något bättre nu"

$A v$ intresse är ordvalet i båda dessa exempel, watt föra in relationen terapeut-patient", resp. watt föra in mig som terapeut $\mathrm{i}$ relationen med patienten«. Orden har en karaktär av penetration. Faderns penetrerande och moderns mottagande resulterar $i$ att något nytt skapas. Då terapeuten talar om att sföra in sig själv i terapirelationen, skapas också något nytt, en ny mening.

EX.«Det svåraste har varit att prata om relationen mellan mig och den ena patienten, även om det är lättare nu, men det var svårt att komma igång،. Med min andra patient har det gått mycket bättre. Jag tror svårigheten med den första patienten beror på att vi är ganska lika i vår problematiku. Om man upplever sig identisk med någon är det svårt att inta ett utifrånperspektiv och använda metakommunikation.

EX. »Det är svårt med den erotiska överföringen, att hantera den på ett bra sätt och att tala om den. Svårigheten beror på detta att få uppmärksamhet som man". Det är klart att om terapeuten har behov av att avnjuta det erotiska inslaget i överföringen, blir det svårt att tala om den.

Ett flertal exempel illustrerar hur en gryende förståelse för överföringen börjar ta plats i terapeutens medvetande. Då terapeuten börjar förstå att han/hon kan representera en person ur patientens förflutna eller nuvarande liv, infinner sig en känsla av frihet. Terapeuten tror inte längre att han/ hon nödvändigtvis besitter alla de egenskaper som patienten tillskriver honom/henne.

EX. "Det innebar en svårighet att övergå från stödkontakt till terapikontakt men när det väl blev så, har det visat sig fungera mycket bra: Har lärt mig en hel del på detta, bl.a att kunna ta emot patientens besvikelse och ilska gentemot mig, föra tillbaka till patienten och vi har använt detta konstruktivt". Patientens negativa känslor mot terapeuten blir hanterbara och kommunicerbara då terapeuten kan särskilja egna känslor från patientens.

EX. "Jag var till en början snar till att ta på mig allt som hände i terapin, som ett misslyckande, men ser det i dag på ett annat sätt. Mycket kan hända i en terapiprocess. Jag kände mig ofta förvirrad i början och tyckte det var mycket svårt. Även här tog jag på mig detta och kände detta som ett misslyckande. Jag kan idag mer se att det kan röra sig om överföringar. Om patienten är förvirrad, känner jag mig förvirradu. Terapeuten introjicerade tidigare allt misslyckande som fanns.

EX. "Min patient hyste misstro och tyckte att jag ställde för höga krav. Det dröjde ett tag innan vi kom nära varandra. Personligen upplevde jag oförmåga att ställa rätta frågor m.m. I handledningen pågick en parallellprocess. Min handledare ställde för höga krav; jag fick ej hjälp att hantera situationen. När jag till sist vågade ta i detta, och min handledare hjälpte mig se vad det handlade om, förändrades relationen mellan mig 
och patienten. Att jag gått i egen terapi var en klar fördel $\mathrm{i}$ handledningen. Jag vågade vara betydligt öppnare och ta upp det som hände mellan mig och handledaren «. Detta exempel illustrerar hur komplicerade processer terapeuten nu är förmögen att fånga. Dessutom tillämpas de nyvunna kunskaperna om metakommunikation även i handledningen. Terapeutens mod att öppet tala om relationen till handledaren resulterar i en förändrad relation inte bara mellan terapeut och handledare utan även mellan patient och terapeut.

\section{Att vänta}

Svårigheter förknippade med att invänta, avvakta och hålla sig tillbaka, när man egentligen har lust att göra något, säga något, hjälpa, förklara, vägleda, stödja är terapeuterna synnerligen upptagna av. Den stora mängden exempel speglar detta dilemma.

EX. "Att invänta patientens egna insikter, att avvakta med tolkningar och att vänta ut patienten«. Av intresse är ordvalet svänta utı som antyder en kampsituation.

EX. "Svårt är att hålla tyst och följa processen. När jag ser patientens problematik är det tålamodsprövande att vänta in patienten och inte försöka hjälpa henne på traven". Det är frestande att omedelbart förmedla till patienten vad terapeuten har förstått. $\AA$ andra sidan låter det som att terapeuten anser det vara fel att vilja hjälpa patienten på traven!

EX. »Det är svårt att vara passiv, att inte ställa ledande frågor, det är svårt att göra patienten frustrerad (abstinensregeln), att inte få »vara duktig» utan ställa »dumma frågorı. Svårigheterna beror på min konflikträdsla och att jag har lite för lätt att vara trevlig och charmerande och så tycker jag att jag har så bra förslag på lösningar och det är svårt att inte få tala om dom för patienten". Att vänta är en utmaning; väntandet upplevs som en mycket passiv och frustrerande aktivitet.

EX. »Mina patienter är djupt deprimerade, och jag känner ibland att jag skulle vilja 'hjälpaı dem mer trots att jag inser att terapi tar tid«. De svåra, tunga känslorna skall bäras av terapeuten under en lång väntans tid.

EX "Jag har ibland haft för bråttom att hjälpa patienten till förklaringar. Jag måste lära mig att stå ut med att vänta tills det händer något med patienten«. Terapeuten brottas med att finna rätt tidpunkt då patienten kan ta emot terapeutens kommentarer.

EX."Svårt har varit att fördjupa samtalet och att inte ha för bråttom och tro att jag vet». Vetandet kan vara en illusion, inser terapeuten. Bara tiden kan utvisa.

EX. "Det svåra är att lyssna och vänta in, att inte komma med förklaringar, att låta patienten tala om det hon själv vill och låta henne få styra. Svårigheten beror på att jag ser mig själv för mycket som ıbekräftarer och att jag tar på mig ansvar som borde vara patientens". Terapeuten frestas att fylla väntetiden med att ta över ansvaret för patienten.

EX. "Jag upplever att jag har svårast att inte bli för aktiv, dvs. svara på patientens behov av att jag ska ifylla påı. Jag antar att jag vill svara upp mot min patients behov. Jag känner hennes frustration och vill mildra den. $\mathrm{Nu}$ tycker jag ändå att jag klarar det hyfsat bra, men det väcker mycket hos mig». Patientens starka önskningar, kanske om närhet och trygghet, gör att terapeuten får svårt att vänta. Terapeuten tycks dessutom tro att gratifikation är förbjuden. 


\section{Att särskilja}

En ofta förekommande svårighet som terapeuterna brottades med mot slutet av utbildningen var att kunna särskilja. Det kunde röra sig om att skilja patienten från terapeuten, skilja ut aspekter, avgränsa, benämna, renodla, ta avsked. Föjande exempel illustrerar hur föreställningen om att inte vara separat, särskild, leder till önskan om ett sådant särskiljande.

EX. »Det är för stor likhet mellan patientens och min egen problematik. Detta medförde att jag hade lite svårt att konfrontera; jag blev för isnällw. Den upplevda likheten mellan patienten och terapeuten får konsekvenser av karaktären 'man skall inte kasta sten då man sitter i glashuss.

EX. "Med en av mina patienter känner jag risk för överidentifikation. Jag tror ibland att jag förstår honom så väl, så att jag 'glömmerı att fördjupa mina frågorı. Nyfikenheten blir lidande då terapeuten upplever sig lik patienten.

EX. »Jag och min patient är ganska lika i vår problematik. Jag känner så väl igen mina problem när jag hör henne berätta. Detta har lett till att jag tyckte att det varit svårt att tala om vår relation". Då man liksom är ett med en annan person, blir det naturligtvis svårt att ta klivet ut ur relationen och tala om den.

EX. "Det svåra har varit att hitta en balans mellan att vara tillräckligt nära men att ändå vara avskild så att den terapeutiska ramen hålls, t.ex. att inte dra över tiden«. Exemplet illustrerar hur terapeuten söker integrera två viktiga kompontenter som är helt beroende av varandra: upprätthållandet av den särskiljande terapeutiska ramen som leder till och tillåter en regression (eller närhet med terapeutens ord).
EX. „Svårt har varit att inte agera i motöverföringen. Jag vill gärna ha intressanta patienter, och en patient blev tråkig. Svårigheten beror på att jag ibland blandar in mig självw. Här anar man hur terapeuten blandar ihop sina behov av underhållning med patientens behov av att bli förstådd. Det tycks som om terapeuten ännu ej kunnat uppleva glädjen i att förstå, och därför ter sig patienten tråkig.

Alla dessa exempel illustrerar behovet av att kunna skilja sig själv från patienten, att skilja egna behov, önskningar och känslor från patientens. Man börjar se konsekvenserna av den symbiotiska relationen.

Följande exempel visar behovet av att på annat sätt avgränsa, urskilja, sortera, benämna, skilja ut den unika patienten från alla teorier, att ta avsked.

EX. »Att avgränsa problemet och inte låta terapin flyta utı. Att flyta ut innebär något gränslöst. Det finns en strävan att finna en gräns.

EX. »Att det är svårt att urskilja olika aspekter. Behov av att skilja ut och renodla samtidigit som jag måste ta med alla aspekter för att kunna göra en bra bedömning och pendla mellan känsla och intellekt. Detta kan bero på att jag har ett behov av att veta säkert hur det är, och jag måste stå ut med att detta kan jag sällan säkert veta. Att våga lita på intuition , att lyssna mer på min känsla behöver jag för att komma vidare«. Man hör i detta exempel hur terapeuten arbetar för att skilja ut, benämna, veta vad som är vad inom sig och utanför.

EX. »Det är svårt att sortera allt material«. Terapimaterialet representerar ett kaos och ordning i detta kaos sökes.

EX. »Olika teorier är inte integrerade. De 
kolliderar. Frågor som hur jag ska arbeta med just den här patienten är jag upptagen av. Finns det någon teori eller metod som kan vara speciellt bra för min patient? « Terapeuten vill här urskilja sin unika patient från det kaos av teorier som terapeuten mött.

EX. "Avslutningen blir svår, och jag har inte haft handledning på detta ännu. Allmänt tycker jag det är svårt med avslutningar, vill helst springa ifrån dem. Jag hade själv ingen bra avslutning i min egen terapi«. Den yttersta gränsen, avskedet, närmar sig. Helst vill terapeuten glömma denna verklighet.

\section{Sammanfattning och diskussion}

Vi kan urskilja två framträdande aspekter av svårigheter som terapeutelever brottas med: Att vara sig själv och att vara avskild.

\section{Att vara sig själv}

Att vara sig själv innebär att man är genuin. Man kan vara sig själv endast på ett sätt, även om man kan låtsas vara sig själv på ett flertal sätt (Szasz, 1974). En äkta psykoterapeutisk identitet är ett uttryck för terapeutens äkta personlighet. Detta innebär att den terapeutiska stilen och den personliga stilen är i stort sett samma. Nybörjarterapeuten upplever inte en äkta professionell identitet, och känner inte att han/hon är sig själv. Nybörjaren känner sig ofri, ospontan, konstlad, tvingad att följa ett regelverk.

Vad är det då som hindrar terapeuteleven från att vara sig själv? Det tycks som att sökandet efter en optimal balans mellan gratifikation och frustration utgör en stor utmaning. En obalans i detta avseende leder till ett "falskt terapeutiskt själv«. Gratifikations/frustrationskonflikten återspeglas i ett flertal teman: i upplevelsen av rollkonflikt, i myten om den goda, givande modern, i föreställningen om den perfekta eleven och i problemen med att vänta.

Allt det goda, mänskliga som terapeuteleverna i tidigare yrkesroller gav, upplevs som förbjudet. Den tidigare yrkesrollen framstår i bjärt kontrast till vad som nu förväntas. Man vill gärna bekräfta, få patienten att se ljusare på framtiden, ge närhet, beröm, trygghet, alltid vara till hands. Nybörjarterapeuten vill vara den goda modersgestalt som han/hon föreställer sig att patienten alltid saknat. Han/hon vill vara en god, helst perfekt elev, aktiv, styrande, kunna svara på frågor och prestera påtagliga resultat, inte minst för att få behålla sin patient. Någon ambitionsfri hållning är det inte tal om! Man vill visa vad man kan inför patienten och inför handledaren. Ibland kan man skönja en önskan om att ta över ansvaret för patientens liv. "Community psychiatry promises to bring the day nearer when..... .everyone will take care of everyone else, but no one will take care of himself" (Szasz, 1974, sid. 28). Att vänta med sina kommentarer tills ett tema vuxit fram, har terapeuteleven inte tid med i sin iver att bota. Tystnaden upplevs som plågsam. Det potentiella rummet för reflektion och lek krymper till ett mörklagt ångestrum.

Under utbildningen tycks terapeuterna höra ett påbud som för dem innebär att gå emot sin natur. Neutraliteten tolkas som ett påbud om kylig distans. Det är förbjudet att skratta, leka och vara personlig. Att vänta på patientens initiativ och låta denne avgöra vad han/hon vill tala om, upplevs som ett 
påbud om passivitet. Det tycks förbjudet att inta en stödjande hållning, att påpeka framsteg som patienten gör. Önskan om att hjälpa och trösta upplevs som förbjuden. Detta ter sig paradoxalt för terapeuten, eftersom just denna önskan utgör själva drivkraften -åtminstone den medvetna- till att söka sig till en hjälpande profession.

I romarbrevet 7:19 står det: „Det goda som jag vill, gör jag icke; men det onda som jag icke vill, det gör jagw. Nybörjarterapeuternas romarbrev skulle snarare lyda: "Det goda som jag vill, det får jag icke göra; men det onda som jag icke vill, det måste jag görau?

Om utbildningens budskap övervägande består av råd om frustration eller om terapeuter tolkar budskapen på detta sätt vet vi inte. Man kan nog anta att det ligger en sanning i båda påståendena. Om lärare/handledare uppfattar att gratifikationsaspekten är mer än väl representerad i terapeuternas förhållningssätt, ligger det nära till hands att överbetona frustrationen i förhållningssättet. Då skulle lärarnas/handledarnas romarbrev till terapeuterna lyda: "Det goda som ni vill, det får ni väl göra; men det onda som ni icke vill, det måste ni görau?

Hur abstinensregeln skall förstås är terapeuterna synnerligen upptagna av. Vad innebär frustration? Upplevelsen av konflikt mellan en gratifierande och frustrerande hållning leder för terapeuteleven till att han/hon ej är sig själv. En hel del förvirring finns i tolkningen av abstinensregeln i psykoanalytisk litteratur. Szasz (1974) menar att denna regel innebär att terapeuten följer terapins målsättning, nämligen att patienten skall lära sig om sig själv och utveckla personlig autonomi. "The analyst has no more right to frustrate his patient than to gratify him» (Szasz, 1974, sid. 187).

\section{Att vara avskild}

Att vara avskild, avgränsad betyder att man kan skilja sig själv från andra, skilja egna känslor, önskningar och behov från andras. Denna förmåga till differentiering tycks försämras hos nybörjarterapeuten. Den ångest som upplevs i mötet med patienten, aktiverar försvar, som i sin tur bidrar till att ej use klartu. Det blir svårt för nybörjaren att urskilja vem som är vem, att skilja patientens problem från de egna, att sortera, att urskilja den unika patienten från alla teorier.

Den bristande differentieringen avspeglas i teman som den osynliga patienten, och att inte tala om den relation som pågår. En ökad medvetenhet om differentieringsproblemet kommer till uttryck i teman som en patient blir synlig, att tala om den relation sompågår samt i behovet att särskilja.

Terapeutelevens behov av att patienten gör framsteg, "mår bättre" sammanblandas med patientens behov av att växa i egen takt. Nybörjaren använder sig av grova mått på förändring. Patientens förändring både underskattas och överskattas. De subtila uttrycken för förändring hos patienten uppmärksammas ej. Patienters rapporter om att må bättre, tas nat face value». Patientens kritik av terapeuten, och ännu värre patientens hot om att avbryta terapin, omvandlar terapeuteleven till personliga katastrofer. Det paradoxala är att patienten är särdeles viktig för terapeuteleven, och samtidigt blir han/hon osynliggjord.

Om nybörjarterapeuten ej upplever sig som avgränsad, skild från sin patient, blir det naturligtvis svårt att tala om en interak- 
tion, i vilken båda deltar $i$, att använda sig av metakommunikation. Även den terapeutiska relationen blir därmed osynliggjord. Förmågan att använda metakommunikation kan kopplas till reflektionsförmågan. Vari består då en reflekterande hållning? Enligt Schibbye (1995) innebär reflektion att individen har ett förhållande till sig själv i en kontinuerlig process, där han/hon kan skilja mellan egna och andras upplevelser. Det reflekterande självet har sin grund i att man inte bara kan uppleva sig själv subjektivt från insidan utan också se sig själv från utsidan. Avgränsning, reflektion och metakommunikation tycks således vara processer som står i dialektiska förhållanden till varandra. De främjar varandra.

\section{Den moderliga och faderliga dimensionen}

Att smälta samman och att vara avskild väcker associationer till den moderliga och faderliga dimensionen.

Att vilja återskapa en situation för patienten som liknar den som spädbarnet erbjuds efter födseln kan ses som ett uttryck för terapeutens moderliga anlag. Det lilla barnet får ligga i mjuka filtar, lyssna till vaggsånger och lugnande ord och på olika sätt skyddas från starka, påträngande stimuli. Terapeutens stödjande, skyddande, hållande attityd, terapeutens moderliga anlag, utgör basen för den terapeutiska situationen. Den terapeutiska situationen upprepar de allra tidigaste dragen i mor-barnrelationen, spädbarnets beroende av modern för sin överlevnad. Den ursprungliga hjälplösheten aktiveras. Problem uppstår självfallet om terapeuten, man eller kvinna, tror sig vara-eller är-hindrad från att använda sig av sitt moderliga anlag, om ordet psykoterapi kommer att förknippas endast med kylig distans, frustration, gränssättande.

Förmågan att kunna vänta, att se en relation utvecklas kan ses som ett uttryck för kvinnlighet, "en disposition för moderskap" (Chasseguet-Smirgel, 1991)... "Det skulle alltså kunna vara analytikerns kvinnlighet som skulle tillåta honom/henne att acceptera det långa havandeskap som den analytiska behandlingen utgör på en viss nivå (sid. 66-67). Kanske terapeuter ibland snabbt uppfattar patienters problematik och innehållet i materialet, men utmaningen ligger $\mathrm{i}$ att ha tålamod, att vänta.

I teman som utveckling, separation, differentiering, uppdelning, urskiljning, benämnande, avgränsning finns den faderliga principen. Fadern har en avgörande roll som gränssättare. Allt det som åtskiljer kan anses som en representande fadern. Fadern som hindrar barnet att àtervända till moderlivet och till en tidig symbiotisk relation med modern. Frånvaron av en introjektion av fadern förstärker tillflykten till en symbiotisk passiv relation. Den faderliga dimensionen är oumbärlig för logiskt tänkande och för förnuft. Om det vakna tänkandet fungerar enligt lustprincipens och primärprocessens lagar, skulle detta resultera i förvirring och kaos. En förening med den arkaiska modern skulle därmed fullbordas. Det omedvetna skulle segra över det medvetna.

Den moderliga och faderliga dimensionen kan anknytas till våra två förmågor, dels förmågan att uppleva symmetri, en grundläggande förmåga till identitietsskapande, dels förmågan till att skapa asymmetri, att separera ut och särskilja. I en symmetrisk relation är båda leden baserade på överen- 
stämmelse (om du står nära mig, står jag nära dig). Man tar fasta på allt som är identiskt. I en asymmetrisk relation finns ingen överensstämmelse (om du är min far, så kan jag inte vara din far). Man tar fasta på det som särskiljer.

Det medvetna sättet att vara styrs av en asymmetrisk princip. Man särskiljer fenomen, upplever gränser, kategoriserar. Det medvetna bygger på förmågan att uppleva distinktioner. Grunden för det omedvetna är däremot en symmetrisk prinicip, ett slags sammanvävande tillstånd, där olikheter ej finns. I projektion, projektiv identifikation, i drömmens förtätning och förskjutning verkar symmetriprincipen. Associationer i poesi och psykoterapi är också symmetriskt sammanknytande.

Terapeutens moderliga funktion och dispositionen för moderskap, hans/hennes kvinnlighet, utgör en nödvändig men ej tillräcklig förutsättning för psykoterapeutiskt arbete. Moderligheten måste ha sina gränser. Annars riskerar symbiosen att aldrig upplösas. Den symmetriskt sammanvävande principen skulle ta överhand. Terapeutens faderliga funktion, att särskilja, avgränsa, benämna, separera utgör garant för att patienten inte slukas av modern, den moderliga livmodern. I egenskap av gräns är den terapeutiska ramen representant för fadern, den faderliga dimensionen. I denna ram ingår terapeutens attityd (neutralitet), ett identiskt tidsschema, timmarnas lika längd, ett avtalat arvode. Det finns en dialektisk relation mellan ramen som definition av ett rum och den regression som den leder till och tillåter. Det är som om patienten får ett tomt papper med sina givna gränser, och patienten fyller detta papper med psykiska produkter. Frånvaro av ram omöjliggör den terapeutiska processen eller gör den psykotisk. Terapeuten vakar över ramen.

Man skulle kunna betrakta den moderliga och faderliga dimensionen som motsatser. Det är inte fråga om att ställa faderns och moderns världar mot varandra utan tvärtom att förena dem. Oavsett om terapeuten är man eller kvinna måste båda komponenterna vara väl integrerade i terapeutens personlighet. Mycket tyder på att en sådan integrationsprocess pågick inom terapeuterna. Båda föräldrarna måste finnas $i$ terapeutens psykiska liv. Förmågan att älska, skapa och tänka är beroende av detta.

Studien finansieras av Socialvetenskapliga forskningsrådet.

\section{Referenser}

Buckley, P., Karasu, T. \& Charles, E. (1979). Common mistakes in psychotherapy. American Journal of Psychiatry, 136, 1578-1580.

Chasseguet-Smirgel, J. (1991). De två träden $i$ trädgården. Stockholm: Norstedts.

Chessick, R.D. (1971). How the resident and the supervisor disappoint each other. American Journal of Psychotherapy, 25, 272-283.
Freud, S. (1920/86). Bortom lustprincipen. Jaget och detet. Stockholm: Natur \& Kultur.

Olk, M.E. \& Friedlander, M.L. (1992). Trainees' experiences of role conflict and role ambiguity in supervisory relationships. Journal of Counseling Psychology, 39, 389-397.

Olsson, G. (1991). The supervisory process reflected in dreams of supervisees. American 
Journal of Psychotherapy, XIV, 511-526.

Olsson, G. (1993). Handledning i psykoterapi ur terapeutens, handledarens och forskarens perspektiv (sid. 124-159). ID. Stiwne (Red.) Perspektiv på handledning. Stockholm: Natur\& Kultur.

Olsson, G. (1996a). Självkänsla i obalans: En studie över terapeutelevers uppfattning om sina färdigheter. Nordisk Psykologi, 48, 252-265.

Olsson, G. (1996b). Psykoterapiforskning för psykoterapeuter. Under tryckning i Nordisk Psykologi.

Ralph, N.B. (1980). Learning psychotherapy: A developmental perspective. Psychiatry, 43, 243-250.

Rönnestad, M.H. \& Skovholt, T.M. (1993). Super- vision of beginning and advanced graduate students of counseling and psychotherapy. Journal of Counseling \& Development, 7. 1, 396405.

Schibbye, A.L.L. (1995). Utvikling av personlig og teoretisk refleksjon: om studenters utdannelse i psykoterapi. Nordisk Psykologi, 47, 29-44.

Skovholt, T.M. \& Rönnestad, M.H. (1992). The evolving professional self. Stages and themes in therapist and counselor development. Chichester, England: Wiley.

Spiegel, D. \& Grunebaum, H. (1977). Training versus treating the psychiatric resident. American Journal of Psychotherapy, 31, 618-625.

Szasz, T. (1974). The ethics of psychoanalysis. New York: Basic Books, Inc. Publishers.

\section{Summary \\ Difficulties experienced by therapists in training: to be genuine and to be separate}

Therapists in training were asked to reflect upon difficulties experienced in their psychotherapeutic work with patients. A qualitative analysis was undertaken of trainees' written reports and interview data. Two main aspects of difficulties were identified: firstly, the development of a genuine therapeutic self, congruent with the personality, and secondly, the development of a sense of separateness in relation to the patient.

The development of a genuine therapeutic self was hampered by conflicts about gratification and frustration. Trainees felt that the good, gratifying motherly care, which was adequate to give in earlier professional roles, was no longer accepted. Frustration meant to them being cold and ungiving. Like ambitious pupils, their needs for achievement made them take over the responsibility for patients' lives. It was difficult to wait for patients' initiative and for a theme to develop.

The capacity to differentiate, to feel separate, was impaired due to anxiety activated in the encounter with the patient. To differentiate one's own needs and problems from patients' needs and problems was difficult, thus making the patient invisible. Enmeshed in the relationship with the patient, the trainee was unable to observe this relationship from the outside and use metacommunication as a therapeutic tool. 